\title{
PERBEDAAN DAYA HAMBAT MADN KONSENTRASI $100 \%$ TERHADAP PERTUMBUHAN GINGIVALIS DAN BAKTERI PORPHYROMONAS AGGREGATIBACTER
}

\section{ACTINOMYCETEMCOMITANS}

\section{Indah Wulandari, Emriadi, Kosno Suprianto}

Korespondensi : indahwulandari12@gmail.com Telp:

\section{Abstract}

Periodontal disease is the second common oral health disease after dental caries. Porphyromonas gingivalis and Aggregatibacter actinomycetemcomitans are the main species of bacteria that cause periodontitis. Improper use of antibiotics can cause bacterial resistence to antibiotics. Essential oil from Pogostemon cablin, Benth leaf is an essential oil from herb contains eugenol and terpenoid compounds which can be used as an alternative antimicrobial agent. The purpose of this research was to know the difference of inhibitory effect of Pogostemon cablin, Benth leaf essential oil to Porphyromonas gingivalis and Aggregatibacter actinomycetemcomitans.The method of this research was experimental laboratories with posttest only control group design. This Research was done using disc diffusion method on the Mueller Hinton Agar. The inhibition zone around the disc was measured by sliding caliper. The results were analyzed with non parametric test Mann Whitney.The results showed that Pogostemon cablin, Benth leaf essential oil had the inhibition zone. The inhibition zone againts Porphyromonas gingivalis was 13,47 mm and 41,15 mm on Aggregatibacter actinomycetemcomitans. The statistical test showed that Pogostemon cablin, Benth leaf essential oil can inhibit both bacterial growth with the bigger inhibition was on Aggregatibacter actinomycetemcomitans bacteria growth.

Keywords: Aggregatibacter actinomycetemcomitans, inhibition zone, Pogostemon cablin, Benth leaf essential oil, Porphyromonas gingivalis

Affiliasi penulis : 1. Fakultas Kedokteran Gigi Universitas Andalas,

\section{PENDAHULUAN}

Kesehatan gigi dan mulut merupakan bagian integral dari kesehatan secara keseluruhan dan mempengaruhi kualitas hidup karena memiliki fungsi pengunyahan dan bicara, serta memiliki pengaruh dalam rasa percaya diri seseorang (Kemenkes, 2012; Paliling et al, 2016). Rongga mulut merupakan media yang ideal bagi perkembangan bakteri karena memiliki temperatur, kelembaban, dan nutrisi yang sesuai untuk berkembangnya bakteri. Bakteri yang berkembang dalam rongga mulut, akan menimbulkan masalah kesehatan gigi dan mulut (Gopdianto et al., 2015). Masalah kesehatan gigi dan mulut yang cukup umum ditemukan adalah karies gigi dan penyakit periodontal (Paliling et al., 2016).

Menurut WHO, 10-15\% populasi di dunia menderita severe periodontitis (Jacob, 2012). Dari hasil survei National Health and Nutrition Examination Survey (NHANES) pada tahun 20092012, diketahui bahwa 46\% dari orang dewasa di Amerika Serikat menderita periodontitis. Dari jumlah tersebut, 8,9\% menderita severe periodontitis (Eke et al., 2015). Di Indonesia, menurut Riskesdas tahun 2007 dan 2013, persentase penduduk Indonesia yang mempunyai masalah gigi 


\section{ANDALAS DENTAL JOURNAL}

Fakultas Kedokteran Gigi Universitas Andalas

Jalan Perintis Kemerdekaan No. 77 Padang, Sumatera Barat

Web: adj.fkg.unand.ac.id Email: adj@dent.unand.ac.id

dan mulut meningkat dari 23,2\% menjadi 25,9\% (Pusdatin, 2014). Penyakit periodontal merupakan salah satu permasalahan gigi dan mulut kedua terbanyak setelah karies gigi yang dialami oleh hampir 90\% masyarakat Indonesia (Notohartojo dan Suratri, 2016).

Periodontitis merupakan penyakit inflamasi yang menyerang jaringan pendukung gigi yang disebabkan oleh mikroorganisme spesifik atau sekelompok organisme spesifik, yang menyebabkan kerusakan progresif dari ligamen periodontal dan tulang alveolar dengan pembentukan poket, resesi, atau keduanya. Bakteri gram-negatif seperti Porphyromonas gingivalis, Aggregatibacter Actinomycetemcomitans, dan Bacteroides forsythus merupakan bakteri utama penyebab terjadinya periodontitis. Porphyromonas gingivalis dan Bacteroides forsythus sering ditemukan pada periodontitis kronis, sedangkan Aggregatibacter Actinomycetemcomitans sering ditemukan pada periodontitis agresif (Newman et al.,2015).

Porphyromonas gingivalis membentuk koloni pada sel epitel gingiva. Sel epitel gingiva merupakan bagian terluar dari mukosa gingiva dan berfungsi sebagai bagian penting dari sistem imun tubuh. Porphyromonas gingivalis memproduksi beberapa faktor virulensi sehingga dapat menyerang jaringan periodontal seperti extracellular protease, lipopolysaccharide (LPS), dan fimbriae (Yilmaz, 2008). Porphyromonas gingivalis juga memproduksi capsular polysaccharide (CPS) dan gingipain. (Bostanci dan Belibasakis, 2012).

Aggregatibacter actinomycetemcomitans merupakan agen etiologi primer dari hampir seluruh kasus localized aggressive periodontitis (Newman et al., 2015). Aggregatibacter actinomycetemcomitans membentuk koloni pada celah subgingival dan menyebabkan kerusakan pada jaringan periodontal karena faktor virulensi yang dimilikinya, seperti adhesin, fimbriae, eksotoksin, dan endotoksin. (Aberg, 2015).

Periodontitis diawali dengan kolonisasi bakteri aerob pada permukaan supragingiva dari gigi dan terus berkembang sampai sulkus gingiva. Bakteri memproduksi faktor virulensi yang menyebabkan terjadinya inflamasi dan perubahan pada junctional epithelium yang akhirnya menyebabkan terjadinya poket periodontal. Perubahan pada junctional epithelium diawali dengan proliferasi yang berbentuk seperti jari. Karena adanya aktivitas enzim dan tekanan oleh jumlah bakteri yang semakin meningkat, bagian apikal dari junctional epithelium bermigrasi ke arah apikal dan menyebabkan bagian koronal terlepas dari akar dan digantikan oleh pocket epithelium. Bakteri aerob yang terus berkembang lama-kelamaan akan menciptakan suasana anaerob pada sulkus gingiva dan memberikan kesempatan pada bakteri gram-negatif anaerobik untuk berkembang. Bakteri gram-negatif berkembang secara agresif dan menyebabkan emigrasi 


\section{ANDALAS DENTAL JOURNAL}

Fakultas Kedokteran Gigi Universitas Andalas

Jalan Perintis Kemerdekaan No. 77 Padang, Sumatera Barat

Web: adj.fkg.unand.ac.id Email: adj@dent.unand.ac.id

neutrofil dalam jumlah besar. Perkembangan bakteri dalam jumlah besar dan faktor virulensinya disertai dengan migrasi neutrofil menyebabkan rusaknya epithelial barrier dan terbukanya akses antara pocket epithelium dan jaringan ikat. Rusaknya epithelial barrier menyebabkan hilangnya gradien agen kemotaksis dan menyebabkan neutrofil menetap di jaringan ikat serta berbalik menyerang jaringan ikat dengan melepaskan enzim lisosom, kolagenase, dan substansi lainnya. Jika sistem imun di jaringan ikat tidak mampu membunuh bakteri, maka kerusakan akan berlanjut dan terjadi resorbsi tulang yang pada akhirnya akan menyebabkan poket periodontal (Reddy, 2011).

Perawatan utama untuk periodontitis adalah perawatan bedah dan perawatan non-bedah (Newman et al., 2015). Perawatan non-bedah merupakan perawatan tahap awal dalam rangkaian prosedur terapi periodontal (Zulfa dan Mustaqimah, 2011). Perawatan non-bedah dapat berupa perawatan mekanis dan kimiawi. Perawatan mekanis diantaranya scalling root planning dan kuretase, sedangkan perawatan kimiawi berupa terapi antimikroba menggunakan antibiotik (Andriani, 2012). Antibiotik yang umum digunakan pada terapi periodontitis adalah tetrasiklin, metronidazole, dan amoxicillin. Penggunaan antibiotik juga bisa dikombinasikan untuk meningkatkan efektivitas antibiotik (Rose et al., 2000). Akan tetapi, penggunaan antibiotik yang tidak tepat meningkatkan kejadian resistensi bakteri terhadap antibiotik. Oleh karena itu, dibutuhkan bahan-bahan alami seperti ekstrak dan minyak essensial dari tumbuhan yang dapat menjadi alternatif agen mikrobial (Das et al., 2013).

Minyak esensial yang berasal dari tumbuhan sudah dikenal khasiatnya sebagai antibakteri yang rendah toksik dan ramah lingkungan (Min et al., 2012). Nilam (Pogostemon cablin, Benth) merupakan salah satu jenis tanaman penghasil minyak esensial dan diperdagangkan di pasar perdagangan nasional dalam bentuk minyak yang dikenal dengan nama Patchouli oil (Aisyah et al., 2008). Sekitar 90\% produksi minyak nilam berasal dari Indonesia, seperti Aceh, Sumatera Barat, Sumatera Utara, Kalimantan Tengah, Bengkulu, Lampung, dan Pulau Jawa (Mangun et al., 2012). Di Indonesia, terdapat tiga jenis nilam yang hingga kini sudah dikembangkan, yaitu nilam wangi (Pogostemon cablin Benth), nilam kembang (Pogostemon heyneanus Benth), dan nilam sabun (Pogostemon hortensis Benth). Nilam wangi memiliki kandungan minyak atsiri sebesar 2,5 - $5 \%$, nilam kembang sebesar 0,5 - 1\%, dan nilam sabun sebesar 0,5 - $1 \%$. Dari ketiga jenis nilam tersebut, nilam wangi merupakan jenis yang paling banyak digunakan dalam pengobatan dan sebagai sumber minyak atsiri karena kandungan minyak atsirinya yang cukup tinggi (Dzakwan, 2012). 


\section{ANDALAS DENTAL JOURNAL}

Fakultas Kedokteran Gigi Universitas Andalas

Jalan Perintis Kemerdekaan No. 77 Padang, Sumatera Barat

Web: adj.fkg.unand.ac.id Email: adj@dent.unand.ac.id

Nilam telah banyak dimanfaatkan sebagai obat tradisional, diantaranya sebagai obat pencuci luka, obat disentri, obat diare, obat pencuci rambut, obat wasir dan menghilangkan bau keringat (Dzakwan, 2012). Minyak atsiri daun nilam (MADN) banyak digunakan di bidang kosmetik dan kesehatan gigi dan mulut, seperti parfum, pemberian aroma pada pasta gigi, dan lain-lain. Penelitian menunjukkan bahwa MADN memiliki banyak khasiat seperti sifat antiemetik, aktivitas tripanosidal, antibakterial, antifungal, dan aktivitas antagonis $\mathrm{Ca}^{2+}$ (Min et al., 2012). Selain itu, tanaman ini juga berkhasiat sebagai antioksidan, analgesik, antiinflamasi, antiplatelet, antitrombotik, aphrodisiac, antidepresan, antimutagenik, fibrinolitik, dan aktivitas sitotoksik (Swamy dan Sinniah, 2015).

Daun nilam mengandung minyak atsiri yang memiliki beberapa senyawa kimia seperti eugenol, geraniol, benzaldehid, keton, dan azulen. Selain itu, di dalamnya juga terkandung senyawa golongan terpenoid yang lain seperti seychellen, norpatchoulenol, nortetrapatcoulol, pogostol, dan pogostone yang bersifat antibakteri dan antijamur. Senyawa ini dapat merusak membran sel bakteri dengan cara berikatan dengan protein enzim dan merusak membran sel sehingga dapat menghambat pertumbuhan sel bakteri. Kandungan lain dalam MADN adalah patchoelen ( $2 \%$ ), guajen ( $21 \%$ ), bulsenen, dan patchouli alcohol sebanyak $35 \%$ (Dzakwan, 2012).

Penelitian yang dilakukan oleh Daset al. pada tahun 2013 tentang analisis aktivitas antibakteri dan antifungal dari MADN terhadap beberapa jenis bakteri, dapat disimpulkan bahwa MADN memiliki daya hambat yang lebih baik dibandingkan dengan antibiotik Ampicillin dengan

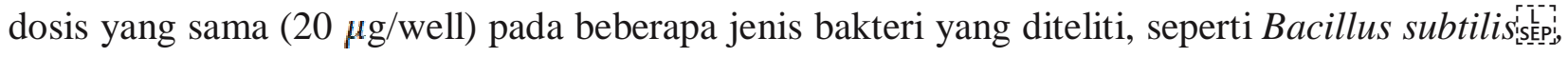
Bacillus cereus, Staphylococcus aureus, Pseudomonas aeruginosa, Shigella sonnei, Vibrio cholera, dan Escherichia coli.

\section{METODE}

Desain penelitian yang digunakan adalah Posttest Only Control Group Design dan jenis penelitiannya adalah penelitian experimental laboratories. Penelitian dilakukan di Laboratorium Kimia Organik Bahan Alam Fakultas Matematika dan Ilmu Pengetahuan Alam Universitas Andalas dan Laboratorium Mikrobiologi Fakultas Kedokteran Universitas Andalas. Penelitian dilaksanakan pada bulan November 2018. Sampel yang digunakan pada penelitian ini yaitu biakan murni bakteri Porphyromonas gingivalis dan Aggregatibacter actinomycetemcomitans yang diperoleh dari Laboratorium Mikrobiologi Fakultas Kedokteran Universitas Andalas. 


\section{ANDALAS DENTAL JOURNAL}

Fakultas Kedokteran Gigi Universitas Andalas

Jalan Perintis Kemerdekaan No. 77 Padang, Sumatera Barat

Web: adj.fkg.unand.ac.id Email: adj@dent.unand.ac.id

\section{HASIL DAN PEMBAHASAN}

Hasil pengukuran rata-rata diameter zona hambat yang terbentuk dapat dilihat pada Tabel 5.1.

Tabel 5.1. Rata-rata diameter zona hambat

\begin{tabular}{lccc}
\hline \multicolumn{1}{c}{ Kelompok } & $\mathrm{n}$ & $\begin{array}{c}\text { Median } \\
(\text { minimum- } \\
\text { maksimum) }\end{array}$ & $\mathrm{x} \pm \mathrm{sd}$ \\
\hline Bakteri Porphyromonas & 18 & $13,15(8,80-$ & $13,47 \pm$ \\
gingivalis & & $18,80)$ & 3,05 \\
Bakteri Aggregatibacter & 18 & $40,00(36,35-$ & $41,15 \pm$ \\
actinomycetemcomitans & & $47,05)$ & 3,58 \\
\hline
\end{tabular}

Keterangan:

$\mathrm{x}=$ rata-rata diameter zona hambat

sd $=$ standar deviasi

Tabel 5.1 menunjukkan bahwa nilai median, minimum, dan maksimum pada kelompok bakteri Porphyromonas gingivalis adalah 13,15 mm, 8,80 mm, dan 18,80 mm. Sedangkan pada bakteri Aggregatibacter actinomycetemcomitans adalah 40,00 mm, 36,35 mm, dan 47,05 mm. Ini menunjukkan bahwa nilai median, minimum, dan maksimum pada bakteri Aggregatibacter actinomycetemcomitans lebih besar daripada bakteri Porphyromonas gingivalis

Uji normalitas Saphiro Wilk didapatkan nilai p < 0,05 yang berarti data tidak terdistribusi normal. Selanjutnya dilakukan transformasi data dengan Cosinus dan didapatkan nilai $\mathrm{p}=0,004$ yang menunjukkan distribusi data tetap tidak normal. Selanjutnya dilakukkan uji homogenitas dan didapatkan nilai $\mathrm{p}>0,005$ yang menunjukkan data memiliki varian yang sama (homogen). Berdasarkan hasil uji normalitas, dapat diartikan bahwa data tidak memenuhi syarat untuk dilakukan uji parametrik $\mathrm{T}$ tidak berpasangan sehingga pengolahan data diuji menggunakan uji non parametrik Mann Whitney. Kesamaan varians tidak menjadi syarat untuk uji kelompok yang berpasangan. Hasil uji Mann Whitney dapat dilihat pada Tabel 5.2. 


\section{ANDALAS DENTAL JOURNAL}

Fakultas Kedokteran Gigi Universitas Andalas

Jalan Perintis Kemerdekaan No. 77 Padang, Sumatera Barat

Web: adj.fkg.unand.ac.id Email: adj@dent.unand.ac.id

Tabel 5.2 Hasil uji Mann Whitney

\begin{tabular}{lccc}
\hline & $\mathrm{n}$ & $\begin{array}{c}\text { Median } \\
\text { (minimum-maksimum) }\end{array}$ & $p$ \\
& & & \\
\hline Bakteri Porphyromonas gingivalis & 18 & $13,15(8,80-18,80)$ & $<0,001$ \\
Bakteri Aggregatibacter & 18 & $40,00(36,35-47,05)$ & \\
actinomycetemcomitans & & & \\
\hline
\end{tabular}

Berdasarkan tabel 5.2, diperoleh angka Significancy 0,000. Karena nilai $\mathrm{p}<0,05$, dapat disimpulkan bahwa terdapat perbedaan bermakna antara kelompok bakteri Poprhyromonas gingivalis dan Aggregatibacter actinomycetemcomitans.

Penelitian ini bertujuan untuk melihat perbedaan daya hambat MADN konsentrasi 100\% terhadap pertumbuhan bakteri Porphyromonas gingivalis dan Aggregatibacter actinomycetemcomitans. Hasil penelitian menunjukkan bahwa terdapat perbedaan daya hambat MADN konsentrasi $100 \%$ terhadap pertumbuhan bakteri Porphyromonas gingivalis dan Aggregatibacter actinomycetemcomitans.

Hasil analisis univariat pada Tabel 5.1 menunjukkan bahwa ukuran zona bening yang terbentuk pada pemberian MADN konsentrasi 100\% terhadap bakteri Porphyromonas gingivalis adalah 13,47 $\mathrm{mm}$ dan terhadap bakteri Aggregatibacter actinomycetemcomitans adalah 41,15 mm.Hasil ini menunjukkan bahwa MADN konsentrasi 100\% memiliki daya hambat terhadap bakteri Porphyromonas gingivalis dan Aggregatibacter actinomycetemcomitans. Berdasarkan pengelompokan daya hambat menurut David dan Stout pada tahun 1971, daya hambat yang terbentuk pada bakteri Porphyromonas gingivalis tergolong kuat karena memiliki diameter antara 10 - $20 \mathrm{~mm}$ dan pada bakteri Aggregatibacter actinomycetemcomitans tergolong sangat kuat karena memiliki diameter lebih besar dari $20 \mathrm{~mm}$.

Berdasarkan analisis bivariat dengan uji non parametrik Mann Whitney didapatkan nilai $\mathrm{p}$ $<$ 0,001 yang artinya terdapat perbedaan daya hambat dari pemberian MADN terhadap bakteri Porphyromonas gingivalis dan Aggregatibacter actinomycetemcomitans. Zonabening yang dihasilkan oleh pemberian MADN pada bakteri Aggregatibacter actinomycetemcomitans lebih besar dari zona bening hasil pemberian MADN pada bakteri Porphyromonas gingivalis, sesuai dengan penelitian Park et al.tentang efek antimikroba linalool dan $\propto$-terpineol terhadap bakteri periodontopatik dan kariogenik pada tahun 2012 yang didapatkan hasil bahwa linalool dan $\propto$ terpineol yang merupakan salah satu komponen senyawa terpenoid lebih sensitif pada bakteri 


\section{ANDALAS DENTAL JOURNAL}

Fakultas Kedokteran Gigi Universitas Andalas

Jalan Perintis Kemerdekaan No. 77 Padang, Sumatera Barat

Web: adj.fkg.unand.ac.id Email: adj@dent.unand.ac.id

Aggregatibacter actinomycetemcomitans dibanding pada bakteri Porphyromonas gingivalis. Terbentuknya zona bening pada daerah sekitar kertas cakram yang direndam dengan MADN menunjukkan bahwa MADN memiliki zat aktif yang dapat menghambat pertumbuhan bakteri Porphyromonas gingivalis dan Aggregatibacter actinomycetemcomitans. Zat aktif yang terdapat pada MADN diantaranya eugenol dan senyawa terpenoid (Dzakwan, 2012). Eugenol merupakan antimikroba karena mampu menyebabkan denaturasi protein pada dinding sel bakteri dengan membentuk struktur tersier protein dengan ikatan nonspesifik atau ikatan disulfide (Andries et al. 2014). Sifatnya yang tidak larut dalam air (hydrophobic) memudahkan eugenol menembus lipopolisakarida dari membran luar dinding sel bakteri dan mengubah struktur dinding sel bakteri sehingga menyebabkan kebocoran pada bagian intrasel dan menyebabkan kematian sel (Paliling dkk, 2016). Sedangkan senyawa terpenoid bekerja dengan menyebabkan lisis pada dinding sel bakteri dengan cara bereaksi dengan porin (protein transmembran) pada membran luar dinding sel bakteri lalu merusak porin. Rusaknya porin berakibat pada pengurangan permeabilitas dinding sel bakteri sehingga bakteri akan kekurangan nutrisi dan mati (Rachmawati et al, 2011).

Perbedaan zona bening yang dihasilkan pada bakteri Porphyromonas gingivalis dan Aggregatibacter actinomycetemcomitans bisa disebabkan oleh perbedaan komposisi struktur dinding sel dari bakteri Porphyromonas gingivalis dan Aggregatibacter actinomycetemcomitans. Mini review yang dilakukan oleh Beveridge pada tahun 1999 mengatakan bahwa gram negatif memiliki membran luar dinding sel yang kaya akan lipid yang terdiri dari protein (termasuk protein porin), fosfolipid, dan lipopolisakarida. Senyawa terpenoid dan eugenol yang terkandung di dalam MADN bekerja dengan mengganggu dinding sel dan porin yang terdapat pada dinding sel bakteri (Das et al., 2016; Rachmawati et al., 2011).

\section{KESIMPULAN}

Berdasarkan hasil penelitian yang telah dilakukan, dapat ditarik kesimpulan bahwa:

1. Terdapat daya hambat MADN konsentrasi $100 \%$ terhadap pertumbuhan bakteri Porphyromonas gingivalis secara in vitro.

2. Terdapat daya hambat MADN konsentrasi $100 \%$ terhadap pertumbuhan bakteri Aggregatibacter actinomycetemcomitans secara in vitro.

3. Terdapat perbedaan daya hambat MADN konsentrasi $100 \%$ terhadap pertumbuhan bakteri Porphyromonas gingivalis dan Aggregatibacter actinomycetemcomitans dengan daya hambat lebih besar pada bakteri Aggregatibacter actinomycetemcomitans. 


\section{ANDALAS DENTAL JOURNAL}

Fakultas Kedokteran Gigi Universitas Andalas

Jalan Perintis Kemerdekaan No. 77 Padang, Sumatera Barat

Web: adj.fkg.unand.ac.id Email: adj@dent.unand.ac.id

\section{KEPUSTAKAAN}

Aberg, C.H., D. Haubaek, F. Kwamin, A. Johansson, dan R. Claesson. 2014. Leukotoxic Activity of Aggregatibacter actinomycetemcomitans and Periodontal Attachment Loss. PloS ONE 9(8): 1-11.

Aberg, C.H., P. Kelk, dan A. Johansson. 2015. Aggregatibacter actinomycetemcomitans: Virulence of its leukotoxin and association with aggressive periodontitis. Virulence 6(3): 188-195.

Aisyah, Y., P. Hastuti, H. Sastrohamidjojo, dan C. Hidayat. 2008. Komposisi kimia dan sifat antibakteri minyak nilam (Pogostemon cablin). Majalah Farmasi Indonesia 19(3):151-156.

Andriani, I. 2012. Efektivitas Antara Scaling Root Planing (Srp) dengan dan Tanpa Pemberian Ciprofloxacin Per Oral pada Penderita Periodontitis. IDJ 1(2): 81-88.

Andries, J.R., P.N. Gunawan, dan A. Supit. 2014. Uji Efek Antibakteri Ekstrak Bunga Cengkeh terhadap Bakteri Streptococcus mutans secara in vitro. Jurnal e-GiGi (eG) 2(2).

Armando, R. 2009. Memproduksi 15 Jenis Minyak Atsiri Berkualitas. Cetakan I. Penebar Swadaya. Jakarta.

Beveridge, T.J. 1999. Structure of Gram-Negative Cell Walls and Their Derived Membrane Vesicles. American Society for Microbiology 181 (16): 4725-4733.

Black, J.G. 2008. Microbiology. $7^{\text {th }}$ ed. John Wiley \& Sons (Asia). Hoboken.

Bostanci, N. dan G.N. Belibasakis. 2012. Porphyromonas gingivalis: an invasive and evasive opportunistic oral pathogen. FEMS Microbiol Lett 333: 1-9.

Carranza, F.D., M.G. Newman, H.H. Takei, dan P.R. Klokkevold. 2015. Clinical Periodontoly. $12^{\text {th }}$ ed. Elseviers Saunders. Toronto.

Chan, M.C., H.K. You, dan S.N. Jeong. 2011. The clinical assessment of aggressive periodontitis patients. Journal of Periodontal \& Implant Science 41: 143-148.

Cheng, Y.W., H.C. Wang, J.M Li, J.Y Wang, K.C. Yang, Y.K. Ho, P.Y. Lin, L.N. Lee, C.J. Yu, P.C. Yang, dan P.R. Hsueh. 2010. Invasive Infections of Aggregatibacter actinomycetemcomitans. Journal of Microbiology, Immunology and Infection 43(6): 491-497.

Clerehugh, V., A. Tugnait, dan R.J. Genco. 2009. Periodontology at a Glance. $1^{\text {st }}$ ed. A John Wiley \& Sons Ltd. Iowa.

Das, P., S. Dutta, J. Begum, dan Md.N. Anwar. 2013. Antibacterial and Antifungal Activity Analysis of Essensial Oil of Pogostemon cablin (Blanco) Benth. Bangladesh J Microbiol 30(1\&2): 07-10.

Diakses pada 20 November 2017. Tersedia:http://digilib.unila.ac.id/2419/12/Bab\%203.pdf

Dibart, S. dan T. Dietrich. 2010. Practical Periodontal Diagnosis and Treatment Planning. $1^{\text {st }}$ ed. A John Wiley \& Sons Ltd. Iowa.

Dietmann, A., A. Milonig, V. Combes, P.O. Couraud, S.C. Kachlany, dan G.E. Grau. 2013. Effects of Aggregatibacter actinomycetemcomitans leukotoxin on endothelial cells.Microb Pathog 61-61(100): 43-50.

Direktorat Jenderal Bina Upaya Kesehatan. 2012. Rencana Program Pelayanan Kesehatan Gigi dan Mulut. Keputusan Direktur Jenderal Bina Upaya Kesehatan nomor: HK.02.04/II/1180/2012HK. Juni. Kemenkes RI. Jakarta.

Dzakwan, M. 2012. Uji Aktivitas Antibakteri Minyak Atsiri Daun Nilam (Pogostemon cablin, Benth) terhadap Staphylococcus aureus dan Escerichia coli. Jurnal Biomedika 5(2): 1-5.

Eke, P.I., B.A. Dye, Liang W., G.D. Slade, G.O.Thornton-Evans., W.S. Borgnakke, G.W. Taylor, R.C. Page, J.D. Beck, dan R.J. Genco. 2015. Update on Prevalence of Periodontitis in Adults in the United States: NHANES 2009-2012. J Periodontol 86(5): 611-622.

Eley B., M. Soory, J.D. Manson. 2010. Periodontics. $6^{\text {th }}$ ed. Elseviers Saunders. New York.

Escobar, A.T., M.D.J. Rodriguez, dan D.R. Demuth. 2014. Integration host factor is required for replication of pYGK-derived plasmids in Aggregatibacter actinomycetemcomitans. FEMS Microbiol Lett 357(2): 184-194.

Fadhilah, A., K. Parisihni, dan H. Sumekar. 2014. Daya Hambat Ekstrak Nannochloropsis oculata Terhadap Pertumbuhan Bakteri Enterococcus $\quad$ faecalis. Denta Jurnal Kedokteran Gigi 8(1): 17-25.

Fatimura, M. 2014. Tinjauan Teoritis Faktor-faktor yang Mempengaruhi Operasi pada Kolom Destilasi. Jurnal Media Teknik 11(1): 23-31.

Gholizadeh, P., A. Pormohammad, H. Eslami, B. Shokouhi, V. Fakhrzadeh, dan H.S. Kafil. 2017. Oral pathogenesis of Aggregatibacter actinomycetemcomitans. Microbial Pathogenesis 113: 303-311. 


\section{ANDALAS DENTAL JOURNAL}

Fakultas Kedokteran Gigi Universitas Andalas

Jalan Perintis Kemerdekaan No. 77 Padang, Sumatera Barat

Web: adj.fkg.unand.ac.id Email: adj@dent.unand.ac.id

Ghom, A.G. 2010. Textbook of Oral Medicine. $2^{\text {nd }}$ Ed.Jaypee Brothers Medical Publishers (P) Ltd. New Delhi.

Gopdianto, R., A.J.M. Rattu, dan N.W. Mariati. 2015. Kebersihan Mulut dan Perilaku Menyikat Gigi Anak Sd Negeri 1 Malalayang. Jurnal e-GiGi (eG) 3(1): 130-138.

Grenier, D. dan S. Tanabe. 2010. Porphyromonas gingivalis Gingipains Trigger a Proinflammatory Response in Human Monocyte-derived Macrophages Through the p38a Mitogen-activated Protein Kinase Signal Transduction Pathway. Toxins 2: 341-352.

Harborne, J.B., 1987. Media Fitokimia Penuntun Cara Menganalisa Tumbuhan. Edisi II. Penerbit ITB. Bandung.

Hariana, A. 2009. Tumbuhan Obat \& Khasiatnya. Seri 2. Penebar Swadaya. Depok.

Highfield J. 2014. Diagnosis and classification of periodontal disease. Australian Dental Journal 54(1 Suppl): S11S26.

Irawan, T.A.B. 2010. Peningkatan Mutu Nilam dengan Ekstraksi dan Destilasi pada Berbagai Komposisi Pelarut. Tesis. Magister Teknik Kimia Universitas Diponegoro. Semarang.

Jacob, S. 2012. Global Prevalence of Periodontitis: a Literature Review. IAJD 3(1). 26-30.

Julianto, T.S. 2016. Minyak Atsiri Bunga Indonesia. Edisi 1. Penerbit Deepublish. Sleman.

Kah, Y.H., Keang P.S., dan Kok G.C. 2016. Porphyromonas gingivalis: An Overview of Periodontopathic Pathogen below the Gum Line. Frontiers in Microbiology 7(53): 1-14.

Kusmiyati dan N.W.S. Agustini. 2007. Uji Aktivitas Senyawa Antibakteri dari Mikroalga Porphyridium cruentum. Biodiversititas 8(1): 48-53.

Kusumawardani, P. Pujiastuti, dan D.S. Sari. 2010. Uji biokimiawi sistem API 20 A mendeteksi Porphyromonas gingivalis isolat klinik dari plak subgingiva pasien periodontitis kronis. Jurnal PDGI 59(3): 110-114.

Lauritsen, N.N. 2014. Classification, Identification, and Clinical Significance of Haemophilus and Aggregatibacter Species with Host Specificity for Humans. Clinical Microbiology Reviews 27(2): 214-240.

Mangun, H.M.S., H. Waluyo, dan A. Purnama. 2012. Nilam: Hasilkan Rendemen Minyak Hingga 5 Kali Lipat dengan Fermentasi Kapang. Penebar Swadaya. Depok.

Min, D. Cheng P., Feng W., dan Fu P. 2012. Antibacterial Activity and Mechanism of Pogostemon cablin Against Bacterial from Milk of Dairy Cow Suffering with Mastitis. Journal of Animal and Veterinary Advances 11(18): 3289-3297.

Mulyadi, M., Wuryanti, dan P. Ria. 2013. Konsentrasi Hambat Minimum (KHM) Kadar Sampel Alang-alang (Imperata cylindrica) dalam Etanol Melalui Metode Difusi Cakram. Chem Info 1(1): 35-42.

Muntaha, A., Haitami, dan N. Hayati. 2015. Perbandingan Penurunan Kadar Formalin pada Tahu yang Direbus dan Direndam Air Panas. Medical Laboratory Technology Journal 1(2): 84-90

Notoatmodjo, S. 2012. Metodologi Penelitian Kesehatan. Rineka Cipta. Jakarta.

Notohartojo, I.T. dan M.A.L. Suratri. 2016. Menyikat Gigi, Konsumsi Buah Dan Sayur, Aktivitas Fisik, Diabetes Mellitus dengan Jaringan Periodontal Gigi di Indonesia Tahun 2013. Buletin Penelitian Sistem Kesehatan 19(4): 219-225.

Nugraheni, K.S., L.U. Khasanah, R. Utami, dan B.K. Ananditho. 2016. Pengaruh Perlakuan Pendahuluan dan Variasi Metode Destilasi terhadap Karakteristik Mutu Minyak Atsiri Daun Kayu Manis (C. burmanii).Jurnal Teknologi Hasil Pertanian IX(2): 51-64.

Ou, D., Xiao-Hong L., Qin-Mei Z. Cheng P., Li G., dan Liang X. 2018. Sesquiterpenoids from the aerial parts of Pogostemon cablin. Phytochemistry Letters 24: 56-59.

Paliling, A., J. Posangi, dan P.S. Anindita. 2016. Uji daya hambat ekstrak bunga cengkeh (Syzygium aromaticum) terhadap bakteri Porphyromonas gingivalis. Jurnal e-GiGi (eG) 4(2): 229-234.

Paju, Susanna. 2000. Virulence associated characteristics Actinobacillus actinomycetemcomittans an oral and non oral pathogen, Dissertation. Univ of Helsinki, Finlandia. pp. 5-32

Park, Soon-Nang., Yun K.L., Marcelo O.F.,Eugene C., Dongchun J., Joong-Ki K. 2012. Antimicrobial effect of linalool and $\propto$-terpineol againts periodontopathic and cariogenic bacteria. Anaerob 18: 369-372.

Pusat Data dan Informasi Kementrian Kesehatan RI. 2014. InfoDATIN. September. Kemenkes RI. Jakarta Selatan.

Rachmawati, F., M.C. Nuria, dan Sumantri. 2011. Uji Aktivitas Antibakteri Fraksi Kloroform Ekstrak Etanol Pegagan (Centella asiatica $(L)$ Urb) serta Identifikasi Senyawa Aktifnya. Prosiding Seminar Nasional "Peranan dan 
ANDALAS DENTAL JOURNAL

Fakultas Kedokteran Gigi Universitas Andalas

Jalan Perintis Kemerdekaan No. 77 Padang, Sumatera Barat

Web: adj.fkg.unand.ac.id Email: adj@dent.unand.ac.id

Kontribusi Herbal dalam Terapi Penyakit Degeneratif. 17 Desember 2011. Fakultas Farmasi Universitas Wahid Hasyim Semarang: 7-13.

Reddy, S. 2011. Essentials of Clinical Periodontology and Periodontics. Jaypee Brothers Medical Publishers (P) Ltd. New Delhi.

Repi, N.B., C. Mambo, dan J. Wuisan. 2016. Uji Efek Antibakteri Ekstrak Kulit Kayu Manis (Cinnamomum burmannii) terhadap Escherichia coli dan Streptococcus pyogenes. Jurnal e-Biomedik (eBm) 4(1).

Rita, W.S. 2010. Isolasi, Identifikasi, dan Uji Aktivitas Antibakteri Senyawa Golongan Triterpenoid pada Rimpang Temu Putih (Curcuma zedoaria ～(Berg.) Roscoe). Jurnal Kimia 4(1): 20-26.

Robinson, T. 1995. Kandungan Organik Tumbuhan Tinggi. Penerbit ITB. Bandung.

Rose, L.F., R.J. Genco, D.W. Cohen, dan B.L. Mealey. 2000. Periodontal Medicine. B.C. Decker Inc. London.

Rukmana, R. 2004. Nilam: Prospek Agribisnis dan Teknik Budi Daya. Penerbit Kanisius. Yogyakarta.

Setiawan, A., S.P. Lastianny, dan D. Herawati. 2013. Efektivitas Aplikasi Madu Murni terhadap Penyembuhan Jaringan Periodontal pada Perawatan Periodontitis Penderita Hipertensi. Jurnal Kedokteran Gigi 4(4): 228235.

Sidiqa, A.N. dan Herryawan. 2017. Efektifitas Gel Daun Sirih Merah (Piper Crocatum) pada Perawatan Periodontitis Kronis. Jurnal Ilmiah Farmasi 5(1): 1-6.

Suwandi, T. 2013. Efek Klinis Aplikasi Subgingival Racikan Gel Metronidasol 25\% dan Larutan Povidon-Iodin 10\% sebagai Terapi Penunjang Skeling-Penghalusan Akar pada Periodontitis Kronis. Jurnal Kedokteran Gigi Universitas Indonesia 10: 669-674.

Swamy, M.K., U.R. Sinniah. 2015. A Comprehensive Review on the Phytochemical Constituents and Pharmacological Activities of Pogostemon cablin Benth.: An Aromatic Medicinal Plant of Industrial Importance. Molecules 20: 8521-8547.

Tortora, G.J., Berdell, R. Funke, Christine, L. Case. 2013. Microbiology: An Introduction, Eleventh Edition. United State of America : Pearson Education.

Wilson, B.A. 2011. Bacterial Pathogenesis. American Society for Microbiology. $3^{\text {rd }}$ ed. Washington, DC.

Yilmaz, O. 2008. The chronocles of Porphyromonas gingivalis: the microbium, the human oral epithelium and their interplay. Microbiology 154: 2897-2903.

Ying, C., Y.G Wu, Y. Xu, J.F. Zhang, X.Q. Song, G.P. Zhu, X.W. Hu. 2014. Dinamic accumulation of sesquiterpenes in essential oil of Pogostemon cablin. Brazilian Journal of Pharmacology 24: 626-634 